\section{After Lisbon Abandon}

\author{
ELIJAH HUGE \\ Wesleyan University
}

I see everywhere that the misfortunes nature imposes upon us are much less cruel than those that we please to add.

—Jean-Jacques Rousseau, "Letter to Voltaire," 1756

Announced by the unplanned, synchronous ringing of bells throughout the city, a series of tremors shook Lisbon on the morning of All-Saints Day, November 1, 1755 in what would become an era-defining urban calamity. Beyond the immediate destruction, the earthquake precipitated a tsunami and widespread fires that collectively killed approximately one quarter of the city's population and destroyed nearly all of its buildings. Both the King, Joseph I, and the Prime Minister, Sebastião de Melo, later named the first Marquis of Pombal, survived.

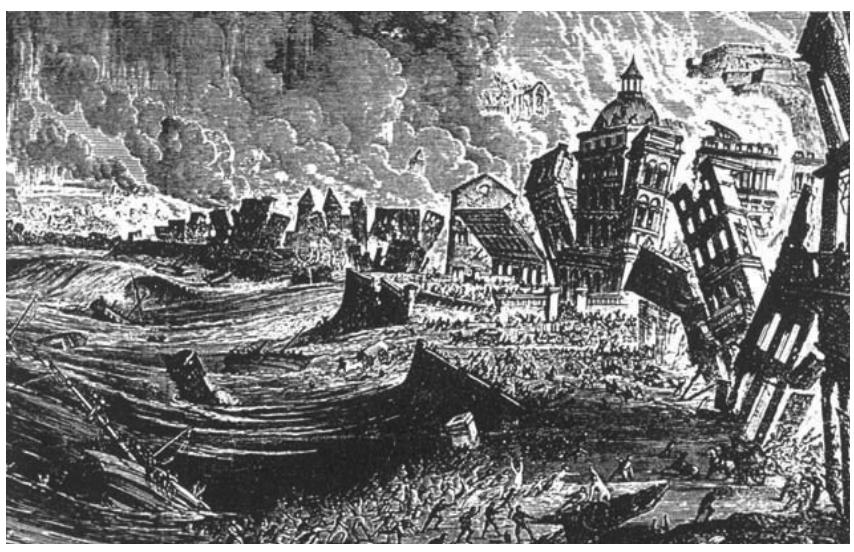

Figure 1: Dramatic depiction of Lisbon along the bank of the Tagus River from east to west showing the effects of the 1755 earthquake: houses exploding into fire, turbulent water, sinking ship, people fleeing. From Georg Ludwig Hartwig, "Volcanoes and Earthquakes: A Popular

Description in the Movements in the Earth's Crust," in The Subterranean World, London, 1887. Courtesy of the National Information Service for Earthquake Engineering, PEER-NISEE, University of California, Berkeley.

The destruction is so extensive that there are initially questions about whether or not is should be rebuilt at all. In fact, one of the four initial proposals by General Manuel da Maia - the architect Melo entrusts with overseeing planning following the disaster - speculates on moving the capital to Belem and abandoning the city (nearby, to the west, where the royal court relocates). The King entertains the idea of simply moving the court to Brazil. Rousseau, in response to a lengthy poem by Voltaire which has generally been interpreted as overtly pessimistic, speculates that the calamity is a social construct:

To continue with your subject of Lisbon, you must admit, for example, that nature had not assembled two thousand six- or seven-story houses there, and that if the inhabitants of that grat city had been more evenly dispersed and more simply lodged, the damage would have been far less, and perhaps nil... You would have wished (as who would not have wished the same?) that the quake had happened in the depths of a wilderness rather than in Lisbon. Can there be any doubt that there also are quakes in wildernesses? But we do not talk about them because they do no harm [mal] to City Gentlemen, the only men of whom we take any notice: indeed, they hardly do any even to the animals and the Savages living scattered in remote places, unafraid of roofs collapsing or houses burning down. But what would enjoying such a privilege mean? Would it then follow that the order of the world has to change according to our whims, that nature has to be subjugated to our laws, and that all we need do in order to forbid it an earthquake in a given place is to build a City there?. ${ }^{1}$

Instead of abandonment, in the years following the Lisbon earthquake, the city would be replanned, modernized, and rebuilt. The royal palace would not. Instead, the king would develop a fear of architectural enclosure and aversion to urban living. In his Historical Memoirs, Sir Nathaniel Wraxall recounts his astonishment, during a visit to the court of Portugal nearly two decades after the earthquake, at the discovery that "Joseph had never slept under a house, properly so denominated, during near seventeen years. Wherever he moved, either wooden Barracks or tents were provided for his accommodation. I have seen tents pitched for his reception, in the fields adjoining the palace of Maffra, while that immense and costly edifice was totally abandoned, neglected, and unfinished." ${ }^{2}$ Rather than return to the palace, the king and his family took up residence in a growing complex of tents and wooden pavilions on the outskirts of Lisbon, colloquially named the Real Barraca.

These remarkably different responses to the earthquake's aftermath represent divergent architectural engagements with environmental crisis. They presage an Enlightenmentera dialectic between technological instrumentality - fueled by nascent forms of performance testing, materials science, 


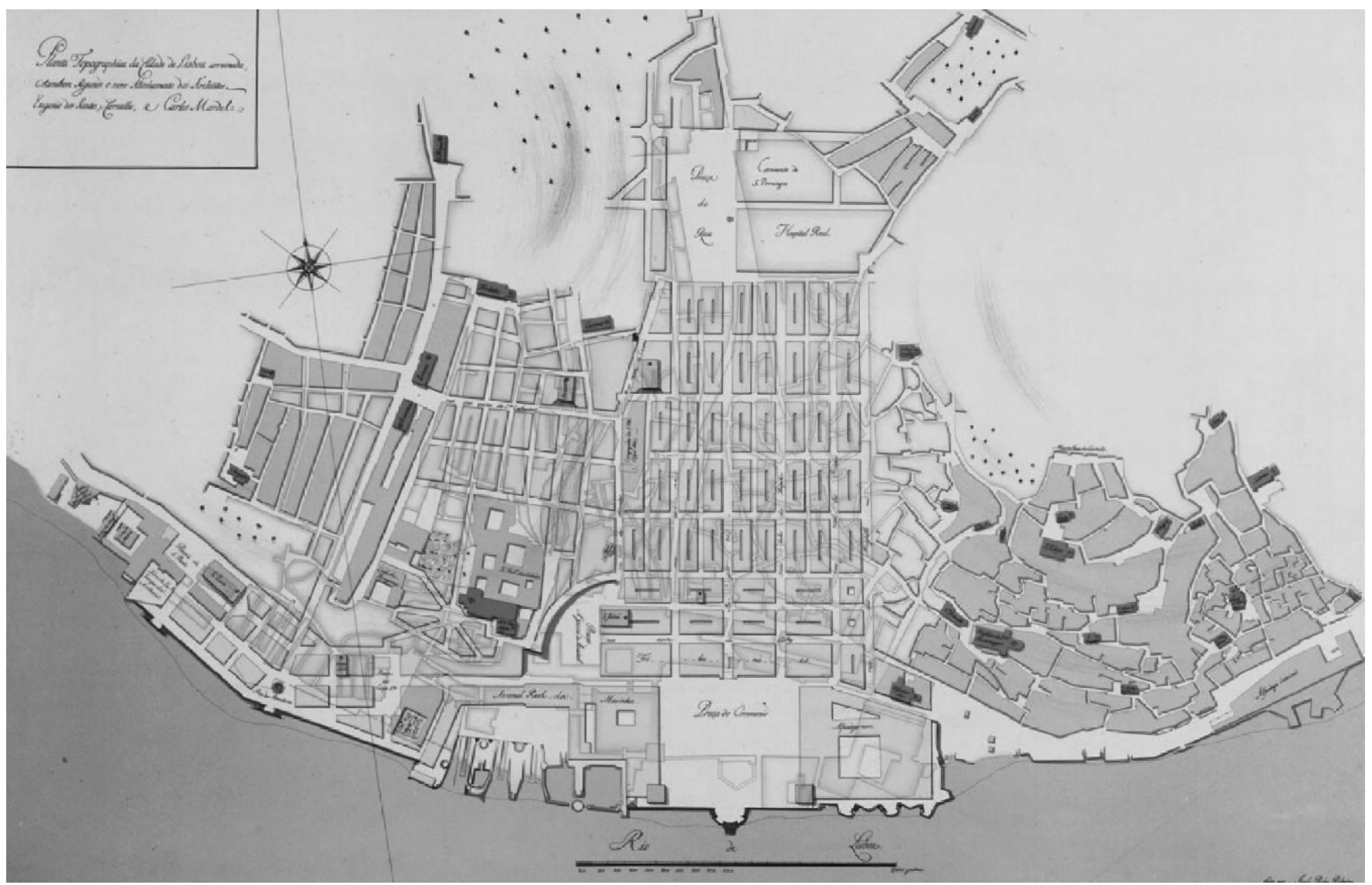

Figure 2: Reconstruction plan showing proposed rebuilding overlaid on pre-existing city platting for the Baixa (Eugénio dos Santos, Carlos Mardel and E. S. Poppe), 1756

and systems integration - and a retreat from technological "overcoming" in favor of a lighter, transient, ephemeral built environment. Both responses foreshadow architecture's current response regimes to the slow crisis of climate change (e.g. "build back better" (BBB), "retreat, rebuild, resist" (RRR), etc.) and offer a pre-history, at the dawn of the scientific age, of the range of positions that have emerged within the discipline relative to unstable and unpredictable climatic conditions.

\section{BAIXA}

From the beginning of his reign, King Joseph I showed little interest in the day-to-day affairs of state, preferring to spend his time hunting, riding, and attending the opera (after the earthquake, there was also a turn to religious activities and the consumption of wine, on the prescription of his doctor). As de Melo continued to demonstrate both his effectuality, and his loyalty, the king's abandonment of his administrative capacities increased until de Melo came to effectively control the operations of government.

After the earthquake, de Melo acted quickly, primarily to ensure continuity for the economy, but also mobilizing the military to police the ruins, prohibiting new building, seeking foreign aid, levying new taxes, and appointing General
Manuel da Maia, eighty-three years of age, a military engineer and architect with substantial experience and knowledge of the city, to oversee post-disaster planning. Maia, in turn, enlisted Captain Eugénio dos Santos and Lieutenant Colonel Carlos Mardel. The team was thus made up of local talent, all military engineers.

Initially, four options were put forward for the future of the city. The first involved reconstruction of the pre-existing conditions, the second focused on widening the streets, but keeping the medieval platting, the third "tabula rasa" involved the Baixa and reconstruction along a new road pattern, at a lower density and with new construction standards. The fourth option proposed that the old city be abandoned and a new capital be built near Belém. Melo, who saw himself as a modernizer, and also saw an opportunity to remake the city in an image aligned with his vision of the nation's future, pursued, the third option.

The plan that de Melo approved, generally credited to dos Santos, is a rectangular grid connecting two large public spaces, the largest the Paços da Ribeiro, on the water (figure 2). It is important to note that this was not simply an exercise in city planning, de Melo also instructed his architectural team 


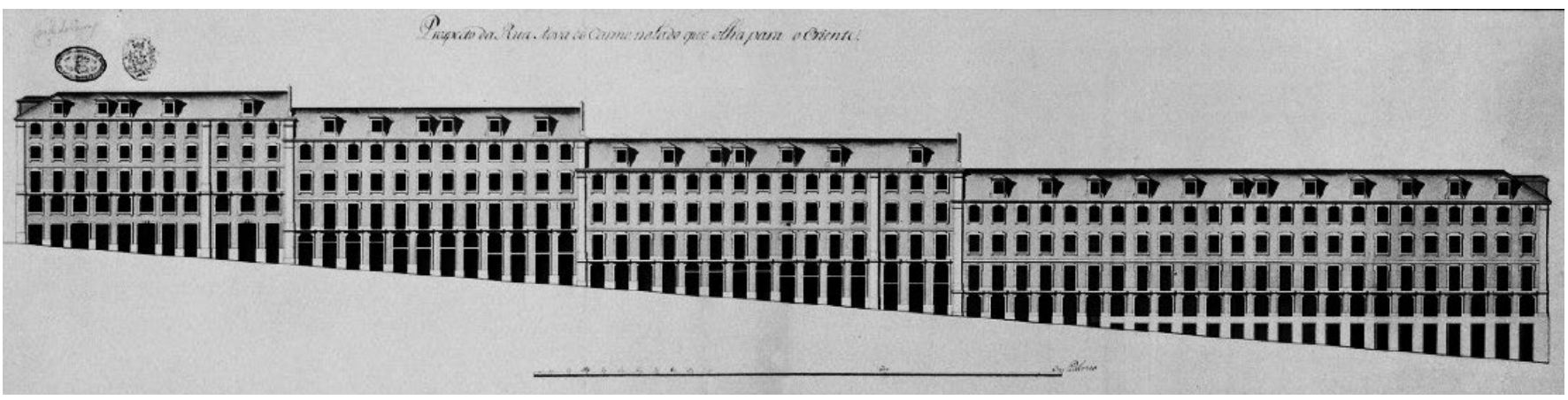

Figure 3: Elevation Drawing of a Baixa Street ("Prospecto da Rua Nova do Carmo no lado que olha para o Oriente": East-facing Elevation of Rua Nova do Carmo), Cartulario Arquivo Municipal de Lisboa, c. 1760

to also design the buildings that would occupy these blocks (figure 3). Landowners are given 5 years to begin construction or risk forfeiture of the land to the state. The city is reimagined as an armature for trade wherein the mercantile class is favored. Using architecture as an instrument of order, de Melo uses architecture as an instrument of order. Embracing technology and prioritizing capital flows (and their protection from future interruption), the plan is carried out through the authority of de Melo's authoritarian regime (figure 4). Under de Melo's supervision, earthquake-resistant, "Pombaline cage" (gaiolo pombalina) wooden framing would be developed, tested, and deployed to reinforce the masonry construction of new city buildings. Military troops, instructed to march in unison around scaled architectural models, were used for the simulation of earthquake conditions to test the performance of these early systematic developments in flexible, lateral bracing. ${ }^{3}$

The result is an architectural project at the scale of the city, or in the words of Alvaro Siza "...the Baixa is like an enormous prefabricated building, planned street by street, and both the construction type and its flexibility were thought for a

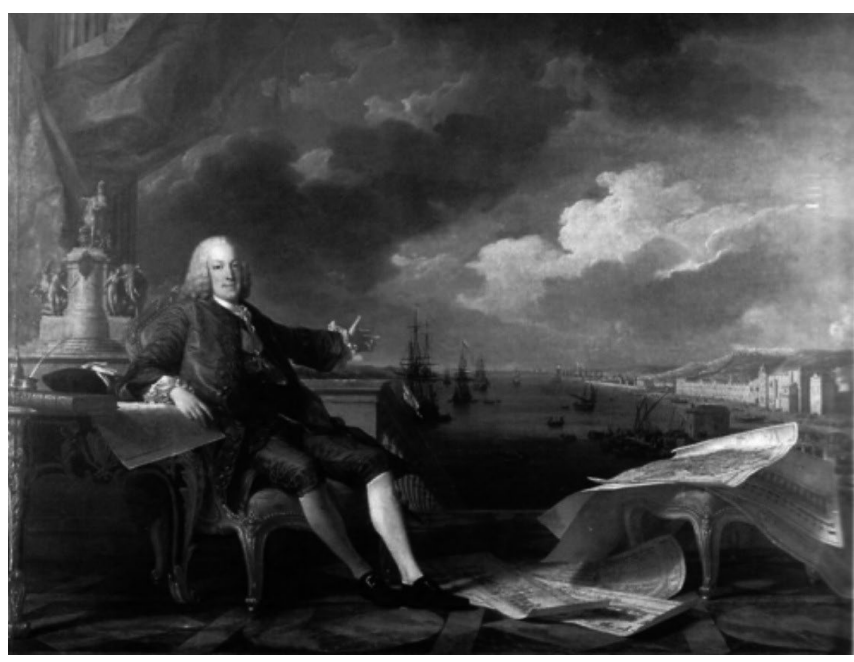

Figure 4: de Melo with architectural plans, gesturing toward a projection of reconstructed Lisbon in the background. Louis-Michel van Loo, Portrait of Sebastião José de Carvalho e Melo, 1st Marquess of Pombal, 1766. massive construction following the same principles" ${ }^{4}$ As variations on this scheme were developed, "Manuel de Maia... vainly attempted to impose two design determinants: that the buildings be no taller than the streets were wide for the obvious purpose of providing passage through the streets after an earthquake, and that a height limitation of two stories be placed on all new construction to limit damage to the buildings themselves." ${ }^{5}$ Neither provisiom made it into the final plans and, as reconstruction took nearly one hundred years to complete, the buildings continued to grow (some are now up to seven stories). Still, this is not an urbanism in an industrial sense of the term. It is the city before the metropolis.

In Lisbon, both the destruction and the response were nearly total. The city itself is conceived as a system - from new sewer infrastructure, to the fire partitions, to the vaulted masonry commercial plinth, to the metal connections of the Pombaline frame. The city is reconstructed by experienced local military architects under the authority of an autocratic prime minister who personally signed the architectural drawings approving individual buildings for implementation. This is one model for managing crisis, and one that is widely can still be seen in use today (what Agamben calls the "State of Exception"). Emergency Studies scholars have argued that the Lisbon earthquake may be considered the first 'modern' disaster because it was the first to evoke a co-ordinated state emergency response as well as a forward-looking, comprehensive effort at reconstruction which included attempts to reduce the impact of future disasters. ${ }^{6}$

\section{BARRACA}

This is to imply that the response was singular, and in some respects it was both singular and autocratic. But, the Baixa is one among a divergent set of state responses. By contrast, the king moves outside the city, to the hills of Ajuda, where he commissions an Italian Theatrical designer, Giovanni Carlo Bibiena, Born in Bologna, to build a new royal palace.

Bibiena had arrived in Lisbon in 1752, hired by the Joseph I to introduce in Portugal popular developments in Italian opera, and Bibiena was committed to put this idea into practice." 
His first commission, the sumptuous Ópera do Tejo, or Royal Opera House, was inaugurated on March 31, 1755, only to be destroyed by the earthquake on November I of the same year (Antigone was the 3rd and last production staged there). Because the king refused to live in a masonry building, instead of a palace, Bibiena designed what has been described as a sprawling wood and canvas complex, with rooms of state draped in scarlet curtains (figure 5). What might be considered a temporary infill project, using parts of pre-existing one and two story masonry buildings at its edges, the result was a kind of stage set for courtly life.

It is hard not to see these two buildings - the Baracca and the Baixa - as contrasting responses to emergency conditions Both are architectures designed in response to a major urban catastrophe emergency conditions at a time when this was beginning to no longer be imagined as an inevitable act of god, but as predictable environmental conditions for which the built environment could be designed. Both reactive and projective, they represent an early attempt to handle emergency conditions holistically using available technology. The relationship between these two projects, as architectures responsive to emergency conditions, could be seen together as a preliminary discourse for the encyclopedia.

More nuanced than a reductivist distinction between architecture as technological artifact on the one hand and a withdrawal from instrumentality on the other, these two paths could be understood to outline a disciplinary spectrum wherein architecture is either enhanced through technological "grafting" (prioritizing stability) or retooled for temporality (prioritizing utility). Using the legacy of these architectural responses to environmental crisis as a backdrop, the paper examines the ways in which architecture's role in emergency is represented and the mercurial relationships between prediction, projection, imagination, invention, and testing that characterize the invariably speculative activity of building for the catastrophic moment.

\section{ENDNOTES}

1. Jean Jacques Rousseau, 'Letter from J.J. Rousseau to M. de Voltaire,' in Rousseau: The Discourses and Other Early Political Writings, ed., trans. Victo Gourevitch (Cambridge: Cambridge University Press, 1997), 234.

2. Sir Nathaniel William Wraxall. "HISTORICAL MEMOIRS OF MY OWN TIME: PART THE FIRST." in Historical Memoirs of My Own Time, 1. Cambridge Library Collection - British \& Irish History, 17th \& 18th Centuries. (Cambridge: Cambridge University Press, 2014), 17. doi:10.1017/CBO9781139814423.002.

3. On the development of Pombaline framing see, for example, Jorge Mascarenhas, Sistemas de Construção V - O Edificio de Rendimento da Baixa Pombalina de Lisboa (Lisbon: Ediçąo Livros Horizonte, 2004).

4. Alvaro Siza, Chiado em Detalhe: Pormenorização Técnica do Plano de Recuperação = Chiado in Detail: Technical Detailing of the Recovery Plan, (Lisboa: Câmara Municipal de Lisboa: Verbo, 2013), 35.

5. Stephen Tobriner, "Earthquakes and Planning in the 17th and 18th Centuries," in Journal of Architectural Education, 33: 4 (Summer 1980): 14.

6. Russell R. Dynes, "The Lisbon Earthquake in 1755: the First Modern Disaster," in The Lisbon earthquake of 1755, Representations and Reactions," eds. Theodore E. D. Braun and John B. Radner (Oxford: SVEC, 2005), 34. Dynes, a founder, along with E.L. Quarantelli and Eugene Haas, of the Disaster

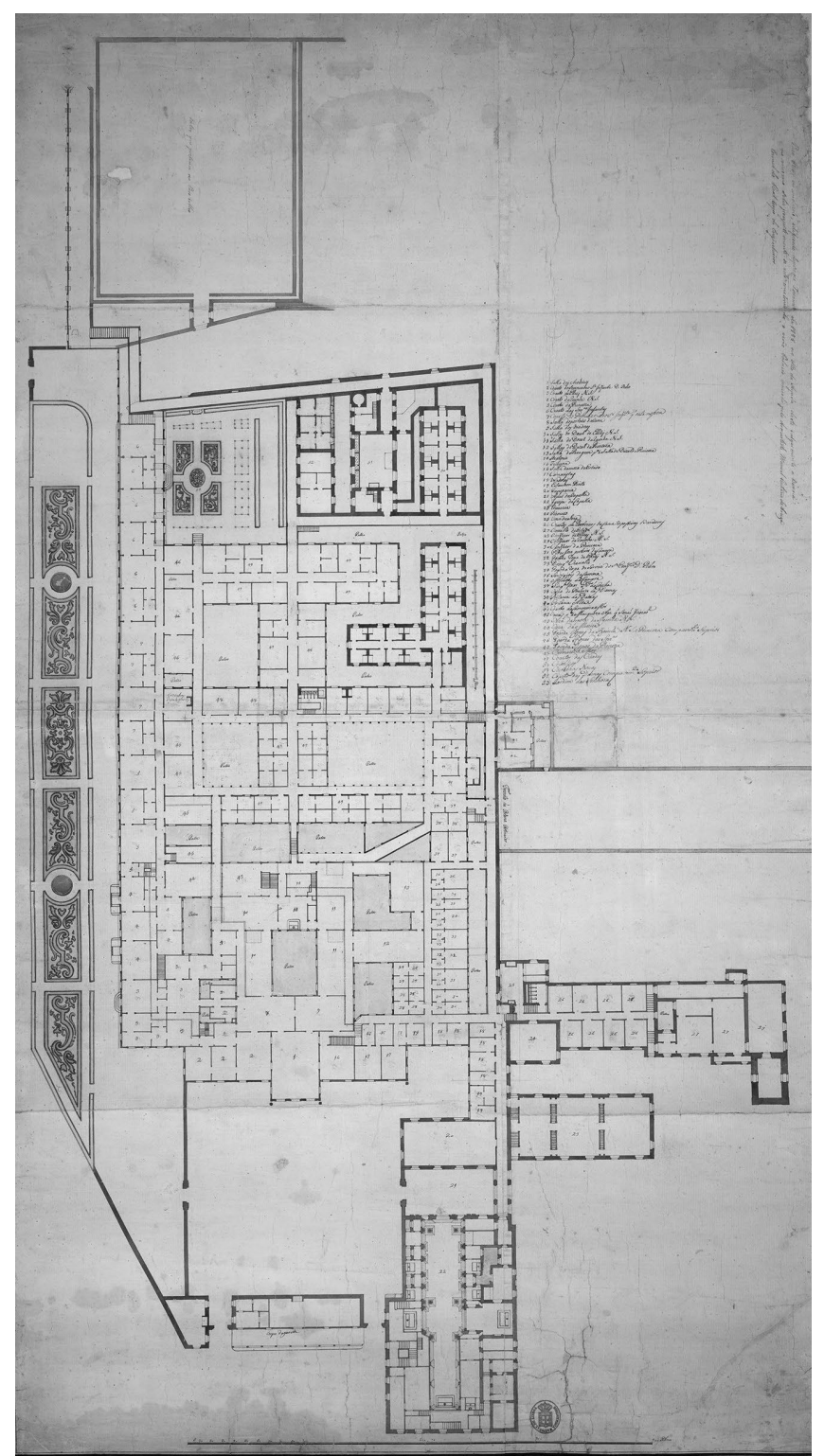

Figure 5: Plan of the Real Barraca, Giovanni Carlo Bibiena, c. 1755.

Research Center at Ohio State, which moved to the University of Delaware in 1985. The Center describes itself as "the first in the world devoted to the social scientific study of disasters."

7. On the history and design of the Real Barraca, see Maria Isabel Braga, Abecasis, Real Barraca: a Residência na Ajuda dos Reis d Portugal após o Terramoto (1756-1794), (Lisbon: Tribuna, 2009). 